\title{
Języki postkolonialności. Wprowadzenie ${ }^{1}$
}

\author{
BOGUSEAW BAKUŁA ${ }^{2}$ \\ (Uniwersytet im. Adama Mickiewicza w Poznaniu)
}

\section{POSTKOLONIALNE TROPY}

Badania nad stanem kultury postkolonialnej w Polsce pojawiają się w związku $\mathrm{z}$ tropami zależności ujawnianymi $\mathrm{w}$ literaturze, filmie, $\mathrm{w}$ architekturze, o wiele rzadziej w polityce czy postawach społecznych. Nie tworzą one spójnej całości metodologicznej, a raczej oferują gamę zróżnicowanych podejść naukowych i publicystycznych, sympatii metodologicznych i rozbiegających się wniosków, dotyczących uwikłania polskiej kultury oraz sąsiednich kultur $\mathrm{w}$ regionie Europy Środkowo-Wschodniej w pozostałości po totalitaryzmach. Literatura, która zajmuje tu centralną pozycję jako podmiot komentujący rzeczywistość pozaliteracką $\mathrm{i}$ jako przedmiot badań, ujawnia liczne problemy wynikające $\mathrm{z}$ pamięci o czasach podległości. W roli najczęściej analizowanej u nas fazy stosunków kolonialnych i następnie postkolonialnych występuje okres PRL-u oraz transformacji ustrojowej po roku 1989. Czas PRL-u cechuje skażenie brakiem podmiotowości i wynikających stąd dysfunkcjonalności różnego charakteru: gospodarczej, społecznej, w sferze kultury, języka, a także relacji międzykulturowych. Ślady zależności nie znikają wraz z dokonanym przełomem politycznym i odejściem kolonizującego hegemona. Pozostają w świadomości jednostek, grup społecznych i zawodowych, w świecie kultury i życia politycznego po roku 1989 jako uraz i jako zakażenie wirusem słabości. Ta infekcja psuje niepodległość, wywiera wpływ na tworzenie prawa i odbudowę państwa, obciąża mentalność zwykłych ludzi i przywódców.

PRL jest najpopularniejszym czasowo obszarem badań postkolonialnych, choć nie bada się go pod tym względem systematycznie. Na uboczu pozostaje okres II wojny światowej, włącznie z Holokaustem, który zyskał status odrębnego dys-

\footnotetext{
${ }^{1}$ Praca naukowa finansowana w ramach programu Ministra Nauki i Szkolnictwa Wyższego pod nazwą "Narodowy Program Rozwoju Humanistyki w latach 2002-2014” w ramach projektu badawczego numer: NPRH 12H 11001880.

2 Correspondence Address: bakula@amu.edu.pl
} 
kursu, a sądzę, że jest również częścią postkolonialnego dyskursu polskiej kultury i historii. Postkolonialiści marginalizują spuściznę po długotrwałych rozbiorach kraju i upadku państwa. Tymczasem Polskę już od roku 1795 do 1989 trapi ciągłość zmieniających się warunków politycznej zależności, brak niepodległego państwa i nadmiar wynikających $z$ tej sytuacji kolonialnych dysfunkcji. Tego stanu nie umniejsza dwudziestoletnia niepodległość z lat 1918-1939. Jak dotąd nie stała się ona przedmiotem badań postkolonialnych, a powinna, albowiem druga Rzeczypospolita, sklejona z trzech zaborów, dość boleśnie zamykała bezpośrednią pamięć o czasach niewoli i usuwała na dalszy plan to, co z nich zostało w świadomości, kulturze, obyczaju politycznym i społecznym Polaków. Wyczytamy to jeszcze w prozie Andrzeja Struga, Stefana Żeromskiego, Zofii Nałkowskiej i wielu innych. Można oczekiwać, że badania w tym kierunku będą jednak podejmowane. Wyjaśnią one na przykład, choć zapewne częściowo, późniejszy stosunek Polaków po 1945 roku do narzuconej, obcej formy państwa socjalistycznego. Dzisiejsza literatura rzadko dostrzega historyczne problemy zależności, które rzutują na niepodległą współczesność. Jeszcze rzadziej sprawy te znajdują się w kręgu krytyki postkolonialnej. Innymi słowy, przed badaniami postkolonialnymi odsłania się właściwie cała trudna historia powstawania nowoczesnego narodu, z rozlicznymi $\mathrm{w}$ tej historii meandrami, traumami i dysfunkcjami, które są skutkiem długotrwałej zależności nie tylko politycznej, ale kulturalnej i mentalnej.

Kolonialność jest traumą, która rzutuje w całości na świadomość i szanse rozwoju narodu. Czym jest, widzimy dzisiaj na przykładzie narodu ukraińskiego, ukraińskiej kultury i ukraińskiego państwa, które heroicznie próbuje odsunąć od siebie widmo upadku i popadnięcia w kolejną zależność od tego samego, zaborczego hegemona. Z kolei postkolonialność, jako bezpośrednia antyteza kolonialności, to pewien stan kultury oraz stan umysłów następujący po okresie traumatycznej, wykorzeniającej, najczęściej obcej dominacji, kiedy to były skolonizowany jeszcze nie potrafi w pełni wydobyć się spod narosłego ciężaru przeszłości, podlega wciąż degradującej jego tożsamość presji języka, kultury i polityki kolonizatora. Oznacza to, że w pewnych sytuacjach były kolonizowany mówi, czy tego chce, czy nie, symbolicznym językiem kolonizatora, że przebijają $\mathrm{w}$ jego kulturze aktywne mentalne, instytucjonalne pozostałości podporządkowania, których nie może zwalczyć, nawet pomimo wprowadzania nowych praw, zwyczajów czy wartości estetycznych. Jak pisała Ewa Thompson, postkolonialność to przede wszystkim stan skolonizowania umysłów.

\section{NASI OKUPANCI}

Zinternalizowany kolonizator i kognitywny świat jego języka w umysłach skolonizowanych lub żyjących w świecie postkolonialnym - to podstawowy problem teorii postkolonialnej. Funkcjonuje on w dwóch wymiarach: zewnętrznym i we- 
wnętrznym. Niezależnie od statusu okazuje się raz przedmiotem, a raz podmiotem kolonizującym, narzucającym swoje rozpoznanie świata, swój język, system wartości, estetykę, obyczaj, które przyjmą tak czy inaczej skolonizowani. Można zatem wyodrębnić kolonizatora z zewnątrz, z innej kultury, grupy religijnej, społecznej, narodowej oraz kolonizatora wewnętrznego, który działa w rodzimej przestrzeni państwowej lub narodowej. W postkolonialnej wersji świata, gdzie trwa walka miedzy kolonizującym i kolonizowanym, wewnętrznym i zewnętrznym opresorem, relacje społeczne, w kulturze, polityce, gospodarce składają się $\mathrm{w}$ ogromnej mierze $\mathrm{z}$ aktów agresji. Terapeutyczny i pedagogiczny sens teorii postkolonialnej polegać ma na odsłanianiu zakresu przemocy i na jej obezwładnianiu poprzez jawność. Nie jest to świat przyjemny, zawiera silną dawkę negatywnych emocji. Podstawowy kłopot krytyki postkolonialnej w Polsce polega na tym, że o ile potrafi ona dokładnie nazwać i scharakteryzować praktyki hegemona zewnętrznego lub tych subalternów, którzy wciąż pozostają w kręgu oddziaływania jego kultury, o tyle ma ogromny kłopot ze wskazaniem podmiotów kolonizacji wewnętrznej. „Nasi okupanci” wyznaczają mniej zbadany wymiar opresji, polegającej na zdominowaniu określonych grup społecznych, etnicznych, zawodowych, seksualnych przez inne grupy lub instytucje. Wiele napisano o życiu społecznym w Polsce po roku 1989, ale mało kto sięgnął ostrzem swojej analizy tak wnikliwie w problemy „okupacji wewnętrznej”, jak 80. lat temu lekarz Tadeusz Boy-Żeleński.

Tadeusz Żeleński-Boy pisał w latach 30. XX wieku o „naszych okupantach”, wskazując na ich wewnątrzspołeczny czy wewnątrznarodowy status, na to, że istnieją $\mathrm{w}$ porozbiorowym, polskim społeczeństwie i tworzą własne mechanizmy dyktatu, narzucające opinie, które marginalizują, wykluczają, stygmatyzują. Żeleński miał na myśli ówczesny, niezbyt oświecony, polski kościół katolicki, któremu wyraźnie nie podobała się emancypacja i oświata, zwłaszcza w sferze świadomego macierzyństwa, ale bez trudu możemy sobie wyobrazić, że "okupantem" w tym szerszym rozumieniu może być każdy podmiot, zbiorowy i indywidualny, który wykorzystuje mechanizmy opresji na własny pożytek podporządkowując i niszcząc Innych. Okupantem (kolonizatorem ograniczającym wolność i prawo człowieka) jest związek osób narzucających np. patriarchalną ideologię pozwalającą na przemoc i molestowanie seksualne, wyzysk ekonomiczny i kulturalny. Okupantem, narzucającym skolonizowaną świadomość zależności, jest partia polityczna nawołująca do konfliktu $\mathrm{z}$ byłym hegemonem w imię swoich wyborczych interesów. Do języka, w którym pobrzmiewa resentyment czy trauma kiedyś zniewolonych, pokonanych, a dziś biorących symboliczny odwet za doznane krzywdy, odwołuje się wielu ludzi i instytucji, znajdując odzew w niemałych grupach obywateli. To kwestia zbiorowej pamięci, traumy, wciąż nawracającego resentymentu, instynktu. 


\section{TEORETYCZNE PROBLEMY}

Drugie znaczenie postkolonialności odnosi się do zróżnicowanej wewnętrznie sytuacji języka teoretycznego (naukowego), w którego ramach byli skolonizowani zamierzają zracjonalizować swoją sytuację poprzez jej badanie, wprowadzanie nowych dialektów teoretycznych, poprzez budowanie świadomości tego, w jaki sposób i w jakim stopniu zbiorowe oraz indywidualne "ja” jest wciąż uwarunkowane (nie)obecnością kolonizującego podmiotu. Owo drugie znaczenie postkolonialności jako języka teorii jest dla samego dyskursu w obecnej chwili znacznie ważniejsze w Polsce, ponieważ jesteśmy wciąż na etapie adaptowania, przyswajania poglądów i oswajania z nimi naszej kultury, naszej świadomości. Dokładniej mówiąc, jesteśmy na etapie tworzenia języków komunikowania w granicach szerokiej teorii. Jest to kwestia kolejnych przekładów klasyków światowej myśli postkolonialnej i ważne zadanie utworzenia własnego zasobu pojęciowego oraz koncepcyjnego. Zróżnicowana $\mathrm{w}$ sobie teoria postkolonialna ma szczególny gen krytyczny, który ustawia ją polemicznie wobec wielu poglądów wywiedzionych z naukowej, narodowej i społecznej tradycji. Jest wyzwoleńcza, antyopresyjna, demaskacyjna i ten romantyczny aspekt stanowi w Polsce, na Ukrainie, Litwie o jej statusie i atrakcyjności. Wobec teorii postkolonialnej stosunkowo obojętni pozostają Czesi i Słowacy, Węgrzy, do których te akurat cechy teorii postkolonialnej nie przemawiają. Wskazane zróżnicowanie na pewno sięga głębszych warstw historycznych, jak również odwołuje się do współczesnej wrażliwości powodowanej okolicznościami społeczno-politycznymi.

W zakresie teoretycznego dyskursu krytyki (teorii) postkolonialnej, która bywa utożsamiana przez wielu badaczy ze światopoglądem (co wedle wciąż obowiązujących kryteriów naukowości powinno eliminować ją z obszaru nauki), mamy do czynienia z kilkoma charakterystycznymi tropami. Widzimy po pierwsze język analizy tekstów literackich, filmowych, plastycznych, publicystyki, architektury, w którym teorię postkolonialną wykorzystuje się w roli narzędzia. Teoria postkolonialna, najczęściej stanowiąca zróżnicowany miks poglądów F. Fanona, E. Saida, H. Bhabhy i G. Spivak, występuje jako aplikacja przydatna w trakcie analizy i interpretacji konkretnych artefaktów. Występuje ona tutaj jako słaba teoria, niekiedy ślad, pretekst, inspiracja, intuicja, skromnie i zgoła nieesencjalistycznie. W literaturze czy w filmie szukamy dowodów na istnienie postkolonialności przejawiającej się jako wykluczający lub upodrzędniający stosunek do Innego, jako konflikt etniczny, polityczny, spór o płeć kulturową czy o prawo do innej seksualności. Tego typu badania cechuje z reguły podejście idiograficzne, aczkolwiek nie jest ono całkowicie pozbawione szerszych podstaw teoretycznych. Tekst literacki pozostaje wartością nadrzędną, a teoria występuje $\mathrm{w}$ formie znaczącego śladu. Z reguły brak tu ortodoksji pojęciowej i ideologicznej, co nie jest rzadkie u teoretyków studiów postkolonialnych. Do tej opcji moglibyśmy zaliczyć większość studiów zamiesz- 
czonych w niniejszym tomie „Porównañ”, które reprezentują typ postkolonialnego case study. Autorzy studiów wyławiają problemy występujące w literaturze polskiej, niemieckiej (postenerdowskiej), ukraińskiej, węgierskiej, serbskiej, białoruskiej, tureckiej, które w większości dotyczą zagadnień tożsamościowych: etnicznych, genderowych, społecznych, a bywa, że i politycznych. Ślad teorii postkolonialnej stawia te problemy w określonym porządku pojęciowym (Inność, upodrzędnienie, wykluczenie, deprywacja, zagrożenie, wykorzenienie, emigracja, trauma) i etycznym, ale przede wszystkim estetycznym. Ten porządek jest marginalizowany przez klasyków myśli postkolonialnej.

Drugi trop mocniej uwzględnia aspekty teoretyczne, które stwarzają miejsce dla kontynuacji, przebudowy, adaptacji języka. W ramach tej opcji spotykamy na łamach „Porównań” teksty Doroty Kołodziejczyk, Hanny Gosk, Tamary Gundorovej. Każda z badaczek reprezentuje inne podejście do teorii. Tekst D. Kołodziejczyk staje się głosem zmiksowanej teorii, jej udoskonalonym, empatycznym wcieleniem. Autorka podejmuje klasyczne problemy wynikające z konfrontacji studiów postkolonialnych z cultural studies: porównywanie, przekładalność, wpływ przekładu literackiego i kulturowego na siłę orientalizacji. Wartością nadrzędną jest dla autorki spójność adaptowanej teorii. Im bliżej pewnego modelu języka teorii tym lepsze wyniki poznawcze, tym większa perswazyjność tekstu teoretycznego. H. Gosk, adaptując postkolonialną teorię, lansuje własną koncepcję postzależności kulturowej w Polsce, jako najbardziej odpowiadającą warunkom postsocjalistycznym. Sprawdza ją na polskiej literaturze po roku 19892. T. Gundorova wykorzystuje związki teorii postkolonialnej z geopolityką, nawiązując do latynoamerykańskich koncepcji peryferyjności, gdzie Inny, ów zasadniczy, zdominowany obiekt studiów postkolonialnych, jawi się w rozmaitych, dynamicznych postaciach. Peryferyjność oraz inność odniesione do sytuacji Ukrainy mają, w koncepcji badaczki, różne oblicza. To ukraińska kobieta w dyskursie patriarchalnym, postać Ukraińca w dyskursie europejskim, ale także Europejczyka w dyskursie globalnym ${ }^{3}$. Ważnym tekstem mówiącym o aktualnej postkolonialnej sytuacji na Ukrainie jest głos Mykoły Riabczuka, który spogląda na problem od strony kulturowo-politologicznej, czym wpisuje się bardziej w następny trop postkolonialności ${ }^{4}$.

Trzecim szerszym tropem $w$ ramach teorii jest uczynienie $z$ niej narzędzia polemiki politycznej, naukowej, a zdarza się, że również publicystycznej. Przekonuje o tym tekst Marty i Marka Skwarów, który niewątpliwie domaga się repliki, jako że formułuje radykalne oceny, wyklucza, oskarża. Język krytyki postkolonialnej

${ }^{2}$ Zob. H. Gosk (red.) (Po) zaborach (po) wojnie (po) PRL Polski dyskurs postzależnościowy dawniej i dziś. Kraków 2913, ss. 600.

${ }^{3}$ Zob. T. Gundorova, Tranzytna kultura. Symptomy postkolonialnoii travmy [Транзитна культура. Симптоми постколоніальної травми]. Kiev 2013, Vyd. "Grani-T”, ss. 546.

${ }^{4}$ M. Riabczuk, Ukraina. Syndrom postkolonialny. Wrocław, KEW 2015, ss. 256. 
staje tu również $\mathrm{w}$ roli przedmiotu krytyki światopoglądowej. Ujmując rzecz szerzej, poza wskazanym tekstem, ten styl pisarstwa, nawiązując do dyskusji o wartości postkolonializmu, wskazuje na znaczną nośność języka postkolonialnego w uporządkowaniu przeszłości, która daje o sobie znać poprzez dysfunkcję strukturalną $\mathrm{w}$ państwie, słabość $\mathrm{w}$ podejmowaniu decyzji politycznych, niezdolność do samodzielnego działania, a jednocześnie demonstrowanie zdecydowanej niechęci wobec kolonialnego dziedzictwa oraz manipulacje $\mathrm{w}$ zakresie idei humanistycznych i naukowych. Wartościowym przykładem korzystania z metodologii postkolonialnej $\mathrm{w}$ porządkowaniu polskiej rzeczywistości intelektualnej i politycznej jest $\mathrm{w}$ tym planie publicystyka Ewy Thompson, choć autorka ta znajduje wielu oponentów. E. Thompson, odwołując się do historii, krytykuje współczesne mentalne, polityczne i strukturalne pozostałości po okresie PRL-u, krytykuje stan umysłów nawiązując przy okazji do czasów, w których dawni Polacy mieli otwarte głowy i byli wolni ${ }^{5}$. Innym wariantem $\mathrm{w}$ tej opcji jest polemika $\mathrm{z}$ językiem współczesnej humanistyki $\mathrm{w}$ imię określonego zwrotu naukowego albo demaskowania tegoż z powodów etycznych, jak czynią to wspomniani M. i M. Skwarowie. Jako ważną możliwość udziału w debacie światopoglądowej, z wykorzystaniem narzędzi krytyki postkolonialnej, należy przywołać odwołujący się do praw mniejszości i praw natury tekst Hanny Mamzer. Połączenie ekokrytyki z refleksją postkolonialną wydaje się $\mathrm{w}$ naszych czasach potrzebne i płodne, nawiązuje do innych tropów we współczesnej humanistyce, dotąd traktowanych marginalnie, jak geopoetyka, geokrytyka, geokulturologia, urban studies. Wzbogaca wrażliwość i warsztat metodologiczny.

Trzy warianty: studia postkolonialne jako aplikacja literaturoznawcza, tekst teoretyczny par excellence, język teorii jako instrument polemiki światopoglądowej i filozoficznej ${ }^{6}$, nie wyczerpują teoretycznych możliwości krytyki postkolonialnej, która rozwija języki swojej ekspresji poprzez przyłączanie różnych pól refleksji humanistycznej.

\section{AUTOREFERENCYJNE I ESENCJALNE ASPEKTY TEORII}

Jakkolwiek to brak wewnętrznej wolności podmiotu i wszelkie rodzaje krępujących go kryptouwarunkowań są przedmiotem teorii postkolonialnej, brak troski o jeden, spójny język może niepokoić. Teoria rozlewa się pomiędzy czymś bardziej swobodnym, co nazywamy krytyką z jednej strony, a z drugiej - światopoglądem. Tymczasem, jeśli sama nie chce stać się przedmiotem kolonizacji, powinna budo-

\footnotetext{
${ }^{5}$ E. Thompson, Sarmatyzm i postkolonializm. „Europa”, nr 137, dodatek do „Dziennika” 18.11.2006.

${ }^{6}$ G. Ch. Spivak, Strategie postkolonialne. Pod redakcją Sarah Harasym. Warszawa 2011, ss. 222, zwłaszcza rozdziały: Krytyka postkolonialna; Praktyczna polityka celów otwartych.
} 
wać kolejne poziomy spójnej autoreferencyjności (metapoziomy) w granicach języka naukowego. Oznacza to, że prawdziwa teoria, jeśli chce się rozwijać, musi z jednej strony konserwować mechanizmy prowadzące do aproksymacji wyników, a z drugiej dbać o swój rozwój w metawymiarze pojęciowym, kognitywnym i behawioralnym. Nie ma pewności czy teoria postkolonialna mieści się w granicach tych parametrów.

Każda teoria ma na względzie wyłącznie siebie, to znaczy, że jest zainteresowana nie tylko spójnością, weryfikowalnością, ale także atrakcyjnością i możliwością rozwoju (zdolnością ewoluowania, przekształcania się). W dzisiejszych czasach te dwa aspekty są bodaj najważniejsze Atrakcyjny musi być przedmiot teoretycznych roztrząsań (najbardziej chwytliwy ze znanych mi, to dotkliwy brak wolności), jak również język. O ile przedmiot pod nazwą „wolność” jest dość banalny w ramach współczesnych ideologii poststrukturalistycznych, z których żadna nie ma zamiaru sławić tyranii, o tyle język staje się trudniejszym i nieoczywistym obiektem teorii, nie tylko w sensie lingwistycznym, ale przede wszystkim kognitywnym oraz metafizycznym. Kognitywny, językowy obraz świata, narzucający względne, nieoczywiste wartości oraz esencjalne traktowanie istoty rzeczy, jako niepozbawionej istotnych, uniwersalnych własności i jakości, ostro dialogują $\mathrm{w}$ teorii postkolonialnej. Postkolonializm rozchodzi się tutaj $\mathrm{z}$ poststrukturalizmem, $\mathrm{w}$ ramach którego umieszcza go wielu systematyków teorii. Demaskuje deformacje, przestawienia, strategie dominacji, upodrzędniania, stygmatyzowanie innością, odebranie wolności, pozostając w kręgu wartości etycznych i esencjonalistycznych. Teoretycy postkolonializmu nie podcinają gałęzi, na której siedzą, to jest przyświecających im oświeceniowych ideałów wolności, równości, przyjaźni. Trudno uwierzyć w wolnościowy światopogląd, który lekceważyłby te idee i rozprawiał przy ich okazji o roszczeniach czy złudzeniach esencjonalizmu. Język postkolonialny w głębszej warstwie znaczeń, w swojej kognitywnej sferze przekonuje, że mamy tu do czynienia z tradycyjną, buntowniczą ideologią przerobioną na metodologię ubraną $\mathrm{w}$ poststrukturalistyczny uniform. Postkolonialiści mają dylemat: ulec presji antyesencjonalizmu, porzucić myśl o znaczeniu istoty rzeczy dla niej samej, zrezygnować $\mathrm{z}$ aksjologii, hierarchizowania, moralizowania, ustanawiania etycznego porządku, porzucić zamiar budowania etycznej koncepcji świata opartej o istotę wartości, czy też pozostać przy swoim, ryzykując wyrzucenie teorii z kręgu akceptowanych idei humanistycznych (tzn. dziś antyesencjonalistycznych). Większość próbuje godzić te dwa poglądy, co wprowadza zamęt i prowokuje zarzuty o dwuznaczność krytyki postkolonialnej. Jej rodowód jest buntowniczy w dwojakim sensie: pojęciowym i społecznym (politycznym, narodowym). Jest to rewolucyjność trochę anarchiczna, bo nikt z klasyków myśli postkolonialnej nie wskazał, co będzie potem, kiedy świat pozbędzie się zarówno kolonializmu, jak i postkolonializmu. Utopia postkolonialna tak daleko nie sięga. Niektórzy jej współtwórcy słusznie uważają, iż lepiej czynią, skupiając się na języku i przywracaniu mu naturalnej, uczciwej referencyjności, która jest mniej za- 
leżna od płynnej, zrelatywizowanej intelektualnej rzeczywistości Zachodu. Narzucająca się w tym momencie autoreferencyjność, w ramach której te zagadnienia zostają podjęte i tak czy inaczej rozstrzygnięte, jest cechą dojrzałości i zdolności do ewoluowania. Stąd teoria, która posiada zasób językowo-pojęciowy zdolny do tego, by ją wewnętrznie transformować, przetrwa, choć nie musi znać końca świata. Można przyjąć, że właśnie ten związek teorii postkolonialnej z rzeczywistością (niektórzy nazywają to patetycznie zwrotem etycznym) i z autoreferencyjnym zasobem językowopojęciowym zapewni jej przetrwanie i dłuższy, choć zapewne modyfikowany, żywot.

\section{MOWA POSTKOLONIALNA}

Mowa postkolonialna rozwija się w warunkach dość szczególnej opresji. Nie ma już oficjalnie kolonizatora (inni mówią - hegemona), ale pozostawił on traumatyczną pamięć o sobie, instytucje, nawyki społeczne, mentalność, zwyczaje językowe, strach. To, paradoksalnie, opresja wewnętrzna. Hegemon pozostawił na miejscu swoich zwolenników, subalternów przyzwyczajonych do beneficjów, kiedyś wysługujących się za kęs przyznanej im władzy, sute napiwki, możliwości funkcjonowania w jego świecie. Pozostawił nawyki, wyćwiczone reakcje, postawy, metody komunikowania. Pozostali jeszcze inni „nasi okupanci”, którzy wzmagają poczucie wewnętrznej opresji. Jeśli istnieje coś takiego, jak językowy obraz świata, to musi istnieć też językowy obraz świata postkolonialnego, zawierającego niebłahe narracje o dokonanej i doznanej przemocy.

Z obserwacji polskiego dyskursu postkolonialnego wynika, że języki postkolonialności mogą mieć charakter lewicowy i prawicowy, w zależności od tego, co uznaje się za główną formę kolonizującą. Lewica kładzie nacisk na upodrzędnianie, wykluczanie, stygmatyzowanie o charakterze społecznym (chętnie wówczas genderowym). Prawica rozprawia o politycznych aspektach (nie)podległości, uznając za jedyną miarę słusznej postkolonialnej świadomości poziom narodowej wolności i możliwość krytyki jej wrogów, dawnych i współczesnych. Oba skrzydła wspierają naszą, nie do końca jeszcze krzepką wolność, zwracając uwagę na to, co najgorsze $\mathrm{w}$ (post)kolonialnych traumach - na zniewolenie ludzi lub ich umysłów, na raniący, opresyjny język i jego dzisiejsze, kognitywne zaplecze... zazwyczaj u strony przeciwnej. Niestety, oponenci pozostają uwięzieni w swoich językach, komunikacja między nimi przyjmuje charakter ideologicznej wojny, w której ważne są poglądy, ale również uprzedzenia, stereotypy, a bywa, że silniejsze emocje.

W Europie Środkowej i Wschodniej zależność, którą można nazwać kolonialną, a następnie postkolonialną ma kilka oblicz ${ }^{7}$. W innej sytuacji pozostają byłe

${ }^{7}$ Zob. też. E. Thompson, Historia Europy Środkowej jako narracja postkolonialna. http://rebelya.pl/post/ 2497/ewa-thompson-o-kolonizacji-europy-srodkowej (data dostępu: 10.12.2014). 
republiki sowieckie na Krymie i w Azji. W innej znajduje się Ukraina, która próbuje uciec ku Europie, wydobyć się z kolonialnego kąta, który dla niej przeznaczyła Rosja. Symbolem tej walki jest toczący się od setek lat spór o język i o ukraińskie prawo do niepodległości. Inne są doświadczenia krajów nadbałtyckich, niepodległych, ale mających niezliczone, niezabliźnione rany. Ten najwyższy stopień uzależnienia, kiedy język hegemona całkowicie dominuje, a używanie ojczystego jest traktowane jako przejaw politycznego buntu, widzimy u jednego z sąsiadów Polski, przyzwyczajonego do roli korzystającego z beneficjów pół-subalterna, niezdolnego do samodzielnego istnienia. W każdym z tych przypadków kwestia języka, w sensie lingwistycznym i kognitywnym, leżała u podstaw stanu postkolonialności. Inna była sytuacja krajów Europy Środkowej, które kontynuowały swoją quasi-państwowość i podmiotowość w ramach systemu sowieckiego i odgrywały w nim wyznaczone role, ale nie dopuszczały do całkowitej rusyfikacji i sowietyzacji w sferze kultury, języka, edukacji, zasad życia społecznego. Z całą pewnością ten uproszczony, ale różnicujący podział można ulokować w sferze kultury i nauki, które nas najbardziej interesują. $Z$ tego powodu nie mamy jednego dyskursu postkolonialnego $\mathrm{w}$ regionie, bo nie ma jednej sytuacji dla wszystkich. Poza tym mamy inne tradycje konfrontowania się z dominująca kulturą. Dla Czechów byłaby nią daleko bardziej historycznie zakorzeniona kultura niemiecka, niż rosyjska, dla Słowaków język i kultura węgierska, dla Polaków rosyjska i niemiecka, dla Litwinów polska i rosyjska, podobnie jak dla Ukraińców i Białorusinów. Przypominanie polskiej dominacji jest zabiegiem czysto politycznym i socjotechnicznym, odciągającym uwagę społeczeństwa litewskiego, białoruskiego i ukraińskiego od rzeczywistego zagrożenia, jakim jest dominacja postsowieckiej kultury rosyjskiej. Kto wierzy w zagrożenie ze strony dawnej Polski, wierzy w to, że pamięć jest, albo powinna być, głównym motorem działań aktualnych, a myślenie o przyszłości zawsze musi brać pod uwagę zło wyrządzone wcześniej. Niewątpliwie jest to kwestia proporcji w uprawianiu resentymentu, bo nikt nie musi się wyrzekać pamięci, ale błędem jest ześrodkowanie wyłącznie na niej życia duchowopolitycznego, jak na przykład na Litwie. Resentyment, uraza, pretensje terytorialne lub spory o przynależność dziedzictwa kultury też są symptomami postawy i mowy postkolonialnej, przejawem stanu mentalnej postkolonialności, niekiedy boleśnie doskwierającej, niekiedy marginalizowanej. Jesteśmy grupą społeczeństw postkolonialnych, które mówią różne treści, ale znajdują się w przestrzeni zbliżonych doświadczeń historycznych. Pytanie, czy potrafią one wyciągać wnioski, stanowiące pożyteczną dla świata odpowiedź na traumę postkolonialności, pozostaje otwarte. 